\title{
Modeling and Optimization of Friction Stir Welding Parameters for Joining Dissimilar Aluminum Alloys
}

\author{
Mohamed Mohamed Abd Elnabi ${ }^{1 *}$, T. A. Osman ${ }^{1}$, A. E. El Mokadem¹, A. B. Elshalakany ${ }^{2}$ \\ ${ }^{1}$ Mechanical Design and Production Engineering Department, Faculty of Engineering, \\ Cairo University, Giza, Egypt. \\ ${ }^{2}$ Production Engineering and Printing Technology Department, Engineering Department, \\ Akhbar El Yom Academy, 6th of October City, Egypt.
}

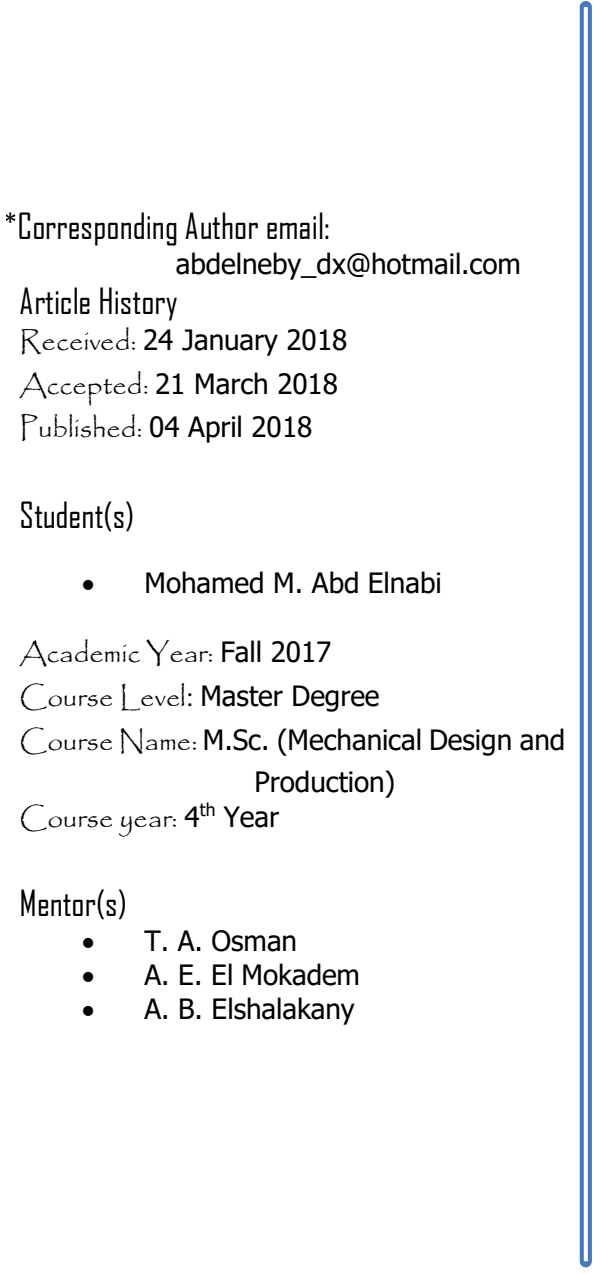

\begin{abstract}
The objectives of this work are to optimize the process parameters on the mechanical properties (ultimate tensile strength (UTS) and ductility) of dissimilar joints between AA5454 and AA7075 produced by friction stir welding and to determine which of them is significant by using Taguchi L16 optimization method. Seven parameters at two levels were selected in this study. The selected parameters are tool rotational speed, traverse speed, pin profile (based on taper angle), D/d ratio, tool tilt angle, plunge depth, and base metal location. Then, mathematical models are built as function of significant parameters/ interactions using Response Surface Methodology. The results of this work showed that the rotational speed, traverse speed, $\mathrm{D} / \mathrm{d}$ ratio and plunge depth are significant parameters in determining UTS (Mean, Signal to noise ratio $(\mathrm{S} / \mathrm{N}))$ at different confidence levels, but pin profile, location of base metal and tool tilt angle are insignificant parameters at any confidence levels. The traverse speed has the highest contribution to the process for UTS about $18.577 \%$ and 16.943 $\%$ for $\mathrm{S} / \mathrm{N}$ ratio and mean, respectively. The accuracy of the models according to the UTS is $97.678 \%$ and $99.56 \%$ for mean and $\mathrm{S} / \mathrm{N}$ ratio, respectively. The maximum joint efficiency, compared to the strength of the AA5454, is $85.3 \%$.
\end{abstract}

Keywords: Friction Stir Welding, Dissimilar Metals, Taguchi Method, Response Surface Methodology, Tensile Strength, Ductility, Process Parameter.

\section{$1 \quad$ Introduction}

Friction Stir Welding (FSW) was invented by Wayne Thomas at TWI (The Welding Institute) in December 1991. FSW is a solid-state joining process that creates high-quality, high-strength joints with low distortion and it is capable of fabricating either butt or lap joints, in a wide range of material thicknesses and lengths. FSW being a solid-state process eliminates many of the defects associated with fusion welding techniques such as shrinkage, solidification cracking and porosity. In the process, a rotating tool is plunged between 
two clamped plates. The heat is produced by the friction action between the material and the tool of the FSW. At suitably generated heat, the base metal will be in a plastic deformation form and the rotating tool stirs the metals from side to side to make a solid joint. Then, the plasticized metals are forged by the shoulder of the tool. Formation of friction stir processing zone is influenced by material flow behavior under the action of rotating tool. However, material flow behavior is mainly affected by tool geometry and welding parameters. The welding process parameters are tool rotational speed, traverse speed, dwell time, plunge depth, axial force, tool tilt angle and base metal location. The tool design parameters are pin profile, shoulder diameter, the ratio between shoulder diameter and pin diameter [1]. Recently, joining dissimilar materials by the FSW method has become a very hot issue. The dissimilar materials can be dissimilar aluminum alloy [2-21], or aluminum alloy to copper [22-24], aluminum alloy to stainless steel and steel [2526], etc. At the condition of aluminum alloys, from previous studies, all the studies of the optimization of FSW parameters on similar or dissimilar joints of aluminum alloys (by Taguchi methods or full factorial design) investigate only two, three or four parameters [4,7-8,10-11,14-21]. They studied the effect of two, three or four parameters from rotational speed, traverse speed, axial force, tilt angle and pin profile with neglecting the effect of the other FSW parameters. It is relatively ineffective on studying a process depending on many parameters due to the neglect the effect of the fixed parameters.

The aim of this work is to study the effect of process parameters on the mechanical properties of dissimilar joints between AA5454 and AA7075 produced by friction stir welding, to optimize these parameters and to determine which of them is significant by using Taguchi optimization method. Experimental work was carried out to produce friction stir welding joints at different levels of process parameters (tool rotational speed, traverse speed, pin profile (based on taper angle), the ratio between shoulder diameter (D) and pin diameter (d) (D/d ratio), tool tilt angle, plunge depth, and base metal location.

\section{Theory of Experimental Design}

Taguchi L16-orthogonal is employed for experiments. The plan of experiment is made of 16 tests in which the first column is assigned to rotational speed ( $\mathrm{rpm})$, the second column to traverse speed $(\mathrm{mm} / \mathrm{min})$, the fourth column to $\mathrm{D} / \mathrm{d}$ ratio, the fifth column to pin profile (based on taper angle), the eighth column to plunge depth, twelfth column to tool tilt angle, eleventh column to location of base metal (Lower metal (LM), AA5454- based on tool rotation direction) and the remaining are assigned to the interactions as shown in Fig. 1 [27]. Table 1 indicates the factors studied and the assignment of the corresponding levels. $\mathrm{S} / \mathrm{N}$ ratios are calculated from the measured values. In this study, the experimentally observed UTS values and ductility values is the higher the better. The related equations are as follows:

$$
\mathrm{S} / \mathrm{N}=-10 \log \left(1 / \mathrm{n} \sum 1 / \mathrm{yi}^{2}\right)
$$

where $\mathrm{n}$ is the number of observations, and $\mathrm{y}$ is the observed data.
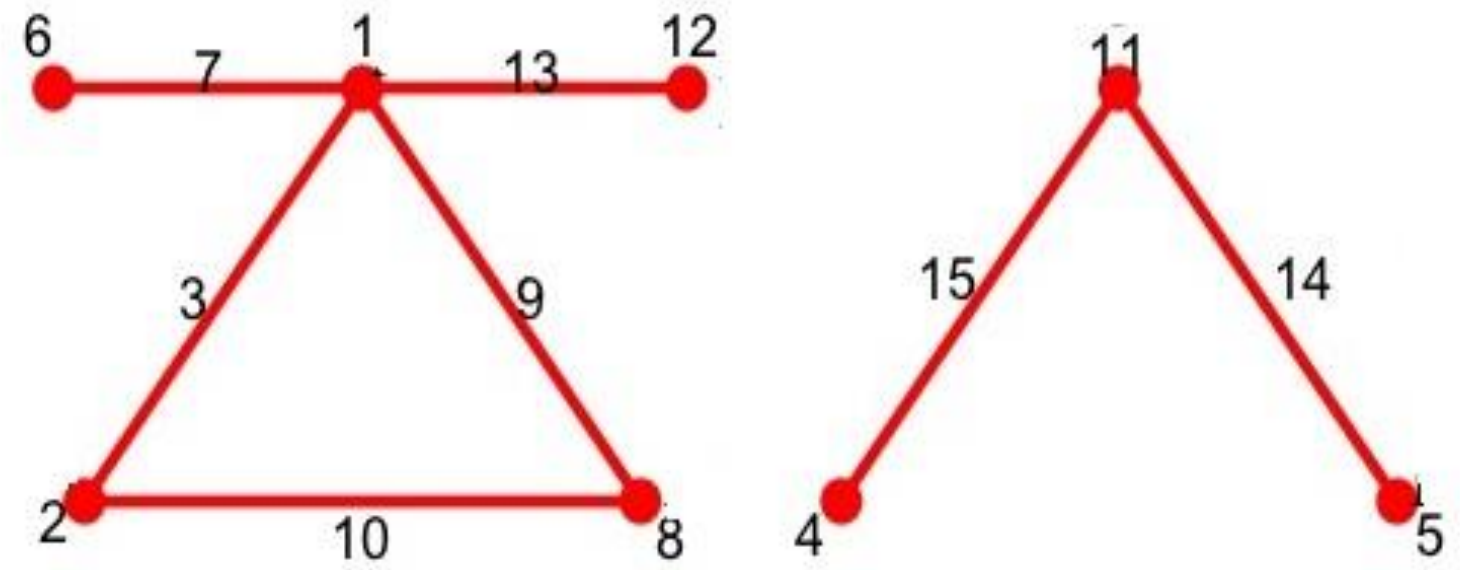

Figure 1: Linear graph for L16-OA 
Elnabi et al., Adv. J. Grad. Res.; Vol. 4, Issue 1, pp: 1-14, July 2018

Table 1: Control variables \& corresponding levels

\begin{tabular}{|c|c|c|c|}
\hline & & Level 1 & Level 2 \\
\hline \multirow{7}{*}{ 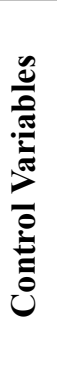 } & Rotational speed (rpm) & 1000 & 1225 \\
\hline & Traverse speed (mm/min) & 17 & 21 \\
\hline & $\begin{array}{c}\text { Pin profile } \\
\text { based on taper angle }\left({ }^{\mathrm{O}}\right)\end{array}$ & $\begin{array}{c}0^{\mathrm{O}} \\
\text { Cylindrical profile }\end{array}$ & $\begin{array}{l}17^{\circ} \\
\text { Tapered profile }\end{array}$ \\
\hline & $\mathrm{D} / \mathrm{d}$ ratio & 3 & 4 \\
\hline & Tilt angle $\left({ }^{\mathrm{O}}\right)$ & $1.5^{\mathrm{O}}$ & $2^{\mathrm{O}}$ \\
\hline & $\begin{array}{l}\text { Location of base metal (LM) } \\
\text { based on tool rotation direction }\left({ }^{\mathrm{O}}\right)\end{array}$ & $\begin{array}{l}\quad-360^{\circ} \\
\text { Retreating side }\end{array}$ & $\begin{array}{l}+360^{\circ} \\
\text { Advancing side }\end{array}$ \\
\hline & Plunge depth $(\mathrm{mm})$ & 0.1 & 0.25 \\
\hline
\end{tabular}

\section{$3 \quad$ Experimental Procedures}

\subsection{Base Metals}

The base metals used in this study are AA5454 and AA7075 of similar plate thickness of $3.5 \mathrm{~mm}$. The chemical composition and the mechanical properties of the base metals are given in Table 2.

Table 2: Chemical composition of the base metals used

\begin{tabular}{|c|c|c|c|c|c|c|c|c|c|c|c|}
\hline & \multicolumn{10}{|c|}{ Chemical composition (wt. \%) } & \multicolumn{2}{c|}{ Properties } \\
\hline Material & $\mathrm{Cr}$ & $\mathrm{Cu}$ & $\mathrm{Fe}$ & $\mathrm{Mg}$ & $\mathrm{Mn}$ & $\mathrm{Si}$ & $\mathrm{Ti}$ & $\mathrm{Zn}$ & $\mathrm{Al}$ & $\begin{array}{c}\text { UTS } \\
\text { (Mpa) }\end{array}$ & $\begin{array}{c}\text { Ductility } \\
\%\end{array}$ \\
\hline AA7075 & 0.28 & 1.59 & 0.16 & & & & & & & & \\
\hline AA5454 & 0.20 & 0.04 & 0.21 & 2.50 & 0.05 & 0.27 & 0.09 & 5.18 & 90.65 & 402 & 10 \\
\hline
\end{tabular}

\section{2 $\quad$ FSW Tools}

The tool parameters selected in this study on the Taguchi array L16 are pin profile and diameter ratio between shoulder diameter (D) and pin diameter (d) (D/d ratio). Two levels of each parameter are used which mean that the array of the tool parameters on the L16-OA contains four different tools. The pin profile was designed based on the taper angle of the pin ( $0^{\circ}$ : cylindrical pin, $0^{\circ}<$ tapered pin). The $\mathrm{D} / \mathrm{d}$ ratio is determined by dividing the diameter of the shoulder to the diameter of the pin at mid-length. The diameter ratios used in this array are 3 and 4. Simple drawing for the four tools is shown in Fig.2 and the dimensions are summarized in Table 3 .

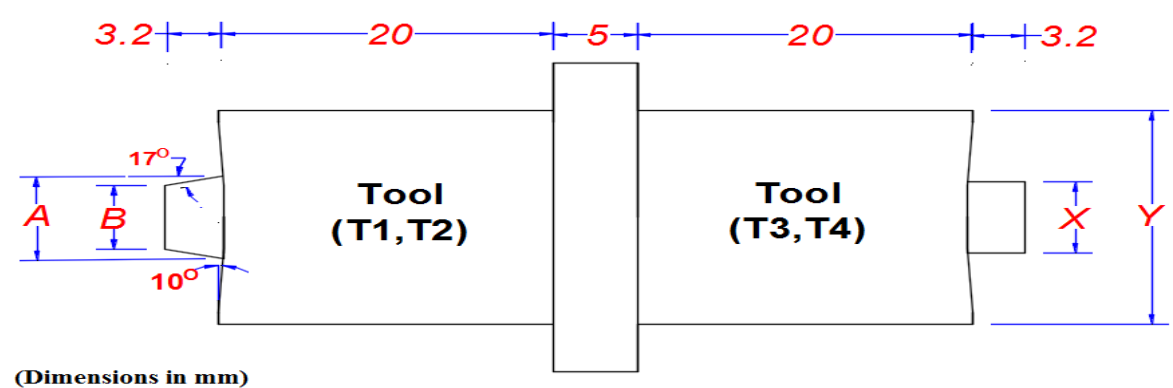

Figure 2: Simple drawing of the FSW tools used

\subsection{Friction Stir Welding Procedures}

The experimental joints were carried out by using a WMW ECKERT vertical milling machine. A butt joint form was used. The direction of the weld line is perpendicular to the rolling direction of the plates. The butt sides of the plates were cleaned and machined using the milling machine to produce a smooth surface and to make suitable butt joints. The base metals were clamped and supported by a steel backing plate. The plates were fixed by using two clamps. Positions and number of clamps are selected after many experimental runs. Fig. 3 shows the dimensions of the plates including the positions of clamps and the location of test specimens for tensile and microstructure. 
Table 3: Specifications of the FSW tools used in the first process (Drawing symbols in figure 2)

\begin{tabular}{|c|c|c|c|c|c|c|}
\hline \multicolumn{3}{|c|}{ Specifications } & Tool 1 (T1) & Tool 2 (T2) & Tool 3 (T3) & Tool 4 (T4) \\
\hline \multirow{2}{*}{ Shoulder } & \multicolumn{2}{|c|}{ Diameter $(\mathrm{mm})(\mathrm{Y})^{*}$} & $\phi 18$ & $\phi 16$ & $\phi 18$ & $\phi 16$ \\
\hline & \multicolumn{2}{|c|}{ Concavity angle $\left({ }^{\circ}\right)$} & \multicolumn{4}{|c|}{$10^{\mathrm{O}}$} \\
\hline \multirow{5}{*}{ Pin } & \multicolumn{2}{|c|}{ Taper angle $\left({ }^{\mathrm{O}}\right)$} & $17^{\mathrm{O}}$ & $17^{\mathrm{O}}$ & $\begin{array}{c}0 \\
\text { Cylindrical }\end{array}$ & $\begin{array}{c}0 \\
\text { Culindrical }\end{array}$ \\
\hline & \multirow{3}{*}{$\varnothing$} & At shoulder & $\begin{array}{c}\text { (A)* } \\
\phi 7\end{array}$ & $\begin{array}{c}(\mathrm{A})^{*} \\
\phi 5\end{array}$ & \multirow{3}{*}{$(\mathrm{X})^{*}$} & \multirow[t]{2}{*}{$(\mathrm{X})^{*}$} \\
\hline & & At mid & $\phi 6$ & $\phi 4$ & & \\
\hline & & At end & $\begin{array}{l}\text { (B)* } \\
\phi 5\end{array}$ & $\begin{array}{c}(\mathrm{B})^{*} \\
\phi 3\end{array}$ & & $\phi 4$ \\
\hline & Length (mm) & From shoulder surface & \multicolumn{4}{|c|}{3.2} \\
\hline
\end{tabular}

(a)

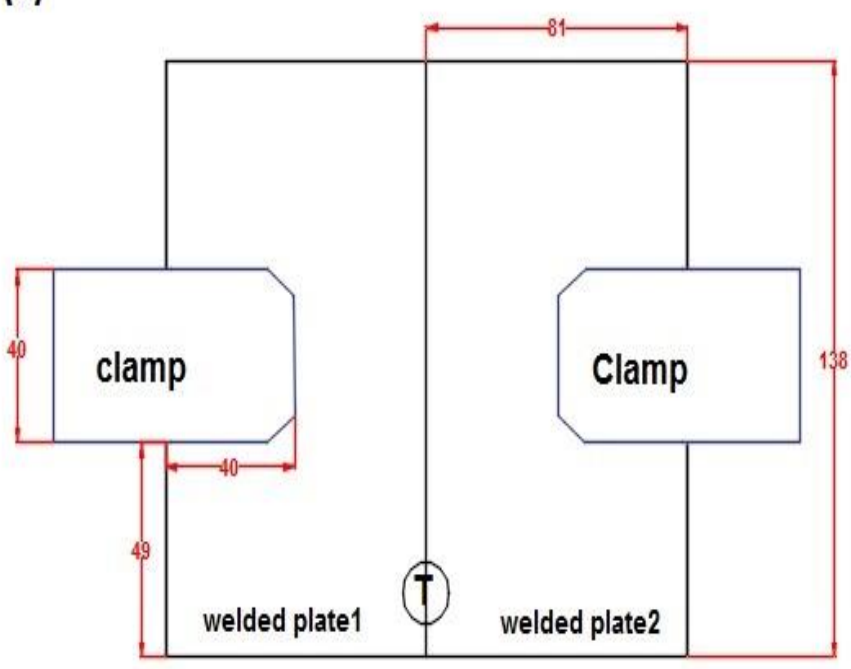

(b)

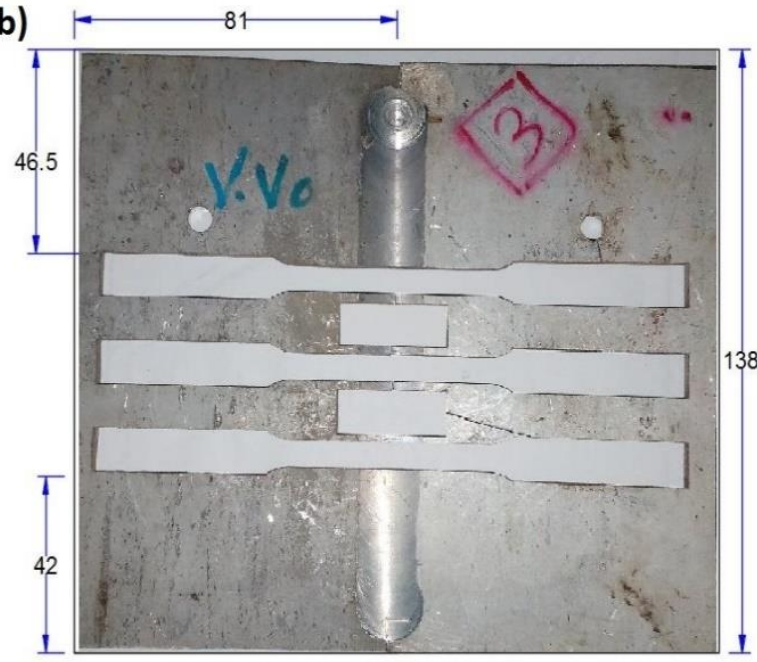

Figure 3: FSW configuration with: (a) position of clamps (b) specimen's location (Dimensions in mm)

\subsection{Tensile Test}

Transverse tensile specimens are used to evaluate the strength of the dissimilar joints. The transverse direction is perpendicular to the welding direction. A universal testing machine was used to perform the tensile test. The tensile specimens were cut by using a wire cut machine according to ASTM B557 [28] and the dimensions of the tensile specimens are shown in Fig.4.

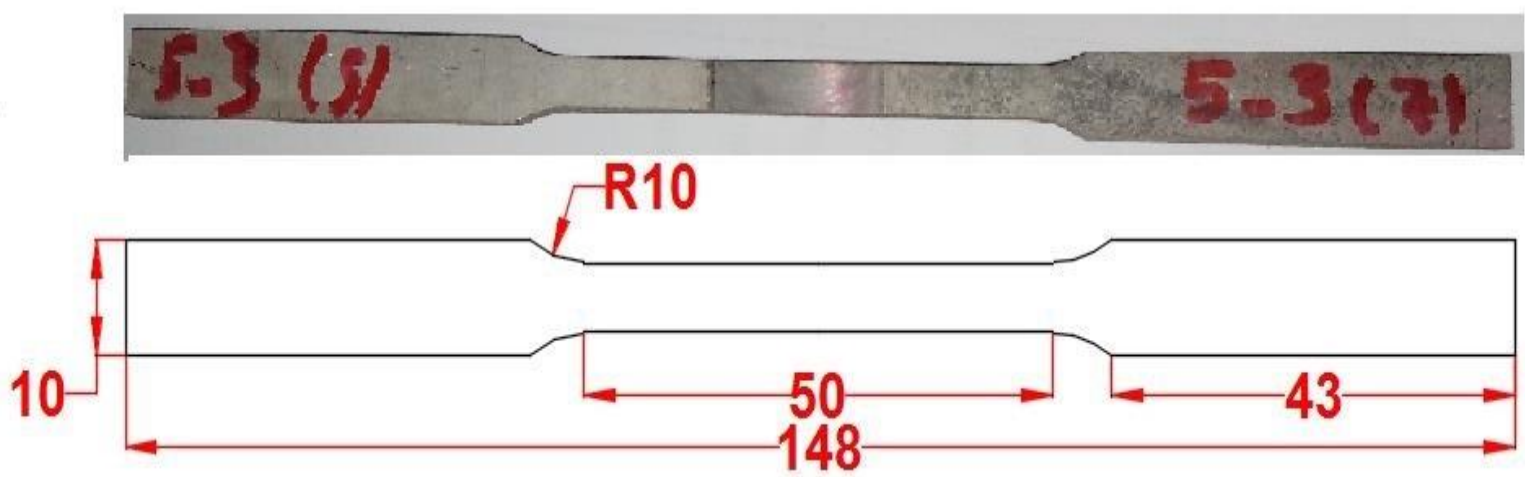

Figure 4 : Tensile test specimen according to ASTM B557 


\section{$4 \quad$ Results and Discussions}

\subsection{Experimental Results Analysis of L16-OA}

Table 4 illustrates the results of the experiments for UTS and ductility according to L16-OA. Also, the results of $\mathrm{S} / \mathrm{N}$ ratio and mean for UTS and ductility are given in Table 4.

Table 4: Experimental results of UTS and ductility according to L16-OA

\begin{tabular}{|c|c|c|c|c|c|c|c|c|c|c|c|c|c|c|c|c|c|c|c|c|c|c|c|c|}
\hline & \multicolumn{14}{|c|}{$\begin{array}{l}\text { Control factors with interactions } \\
\text { (L160A) }\end{array}$} & \multicolumn{5}{|c|}{ UTS (Mpa) } & \multicolumn{5}{|c|}{ Ductility \% } \\
\hline & $\mathrm{X} 1$ & $\mathrm{X} 2$ & $\begin{array}{l}\mathrm{X} 1 \\
\mathrm{X} 2\end{array}$ & $\mathrm{x} 3$ & $\mathrm{X} 4$ & $\mathrm{X} 5$ & $\begin{array}{l}\mathrm{X} 1 \\
\mathrm{X} 5\end{array}$ & $\begin{array}{l}\mathrm{X} 2 \\
\mathrm{X} 5\end{array}$ & $\mathrm{X} 6$ & $\mathrm{x}$ & & \begin{tabular}{l|l}
1 & 2 \\
7 & 2
\end{tabular} & $\begin{array}{l}\mathrm{X} 4 \\
\mathrm{X} 6\end{array}$ & $\begin{array}{l}\mathrm{X} 3 \\
\mathrm{X} 6\end{array}$ & R1 & $\mathrm{R} 2$ & R3 & Mean & $\begin{array}{l}\mathrm{S} / \mathrm{N} \\
\text { ratio }\end{array}$ & R1 & R2 & R3 & Mean & $\begin{array}{l}\mathrm{S} / \mathrm{N} \\
\text { ratio }\end{array}$ \\
\hline 1 & 1 & 1 & 1 & 1 & 1 & 1 & 1 & 1 & 1 & 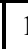 & & . & 1 & 1 & 208.12 & 203.92 & 197.97 & 203.337 & 46.1588 & 9.6 & 9.1 & 8.75 & 9.15 & 19.2097 \\
\hline 2 & 1 & 1 & 1 & 1 & 1 & 2 & 2 & 2 & 2 & 2 & & 2 & 2 & 2 & 199.72 & 195.28 & 185.25 & 193.417 & 45.7169 & 8.4 & 8 & 6.25 & 7.55 & 17.3363 \\
\hline 3 & 1 & 1 & 1 & 2 & 2 & 1 & 1 & 1 & 1 & 2 & & 2 & 2 & 2 & 205.67 & 185.45 & 194.22 & 195.113 & 45.7825 & 9.6 & 7 & 8.4 & 8.33 & 18.1977 \\
\hline 4 & 1 & 1 & 1 & 2 & 2 & 2 & 2 & 2 & 2 & 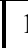 & & . & 1 & 1 & 169.64 & 199.93 & 217.13 & 195.567 & 45.6876 & 6.5 & 8.5 & 9.25 & 8.083 & 17.8518 \\
\hline 5 & 1 & 2 & 2 & 1 & 1 & 1 & 1 & 2 & 2 & 1 & & . & 2 & 2 & 198.87 & 218.68 & 210 & 209.183 & 46.3908 & 9.5 & 11.75 & 9.50 & 10.250 & 20.0872 \\
\hline 6 & 1 & 2 & 2 & 1 & 1 & 2 & 2 & 1 & 1 & 2 & & & 1 & 1 & 206.12 & 208.08 & 202.25 & 205.483 & 46.2537 & 8.75 & 9.4 & 9.25 & 9.133 & 19.2002 \\
\hline 7 & 1 & 2 & 2 & 2 & 2 & 1 & 1 & 2 & 2 & 2 & & 2 & 1 & 1 & 209.14 & 224.18 & 212.69 & 215.337 & 46.6510 & 8.25 & 11.2 & 8.125 & 9.1917 & 18.9949 \\
\hline 8 & 1 & 2 & 2 & 2 & 2 & 2 & 2 & 1 & 1 & 1 & & 1 & 2 & 2 & 182.11 & 182.19 & 181.25 & 181.850 & 45.1942 & 6.5 & 6 & 7.125 & 6.541 & 16.2498 \\
\hline 9 & 2 & 1 & 2 & 1 & 2 & 1 & 2 & 1 & 2 & & & 2 & 1 & 2 & 180.48 & 205.31 & 208.61 & 198.133 & 45.8836 & 7.125 & 7.75 & 8 & 7.6250 & 17.6135 \\
\hline 10 & 2 & 1 & 2 & 1 & 2 & 2 & 1 & 2 & 1 & & & 1 & 2 & 1 & 205.23 & 230.66 & 199.84 & 211.910 & 46.4732 & 9.6 & 9.8 & 8.25 & 9.2167 & 19.2136 \\
\hline 11 & 2 & 1 & 2 & 2 & 1 & 1 & 2 & 1 & 2 & & & 1 & 2 & 1 & 204.57 & 198.29 & 197.68 & 200.180 & 46.0253 & 9.4 & 7 & 8.50 & 8.300 & 18.1848 \\
\hline 12 & 2 & 1 & 2 & 2 & 1 & 2 & 1 & 2 & 1 & & & 2 & 1 & 2 & 203.51 & 190.10 & 186.88 & 193.497 & 45.7159 & 8.2 & 7.5 & 7.50 & 7.7333 & 17.7445 \\
\hline 13 & 2 & 2 & 1 & 1 & 2 & 1 & 2 & 2 & 1 & & & 2 & 2 & 1 & 218.88 & 218.31 & 214.60 & 217.263 & 46.7387 & 11.2 & 9.5 & 8.25 & 9.6500 & 19.4892 \\
\hline 14 & 2 & 2 & 1 & 1 & 2 & 2 & 1 & 1 & 2 & 2 & & 1 & 1 & 2 & 212.24 & 206.53 & 207.96 & 208.910 & 46.3974 & 10 & 8.75 & 8.50 & 9.083 & 19.1007 \\
\hline 15 & 2 & 2 & 1 & 2 & 1 & 1 & 2 & 2 & 1 & & & 1 & 1 & 2 & 199.64 & 207.22 & 200.41 & 202.423 & 46.1216 & 9.6 & 8.25 & 8.25 & 8.700 & 18.7251 \\
\hline 16 & 2 & 2 & 1 & 2 & 1 & 2 & 1 & 1 & 2 & 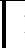 & & 2 & 2 & 1 & 214.50 & 208 & 212.0 & 211.500 & 46.5041 & 8.25 & 8.00 & 8.00 & 8.0833 & 18.1491 \\
\hline
\end{tabular}

\subsubsection{Analysis of Variance for L16-OA}

Table 5 gives a conclusion of the effect of the process parameters, interactions, and its contribution on UTS and ductility. It can evaluate the efficiency of using L16-OA to study seven parameters at two levels by evaluating the degree of statistical errors obtained from ANOVA tables. For UTS, the errors are $0.782 \%$ and $1.347 \%$ for $\mathrm{S} / \mathrm{N}$ ratio and mean, respectively. For ductility, the errors are $11.7 \%$ and $12.9 \%$ for $\mathrm{S} / \mathrm{N}$ ratio and mean, respectively. With these errors, the use of L16-OA to study a process have seven parameters with two levels is very efficient. It means that the process is not affected by any other parameters or interaction variables out of these screen parameters in mean and $\mathrm{S} / \mathrm{N}$ ratio of UTS under this process condition. With these results obtained from ANOVA tables about the process, it can build strong mathematical models. 
Table 5: Summary of the effect of the parameters and interactions on UTS and ductility

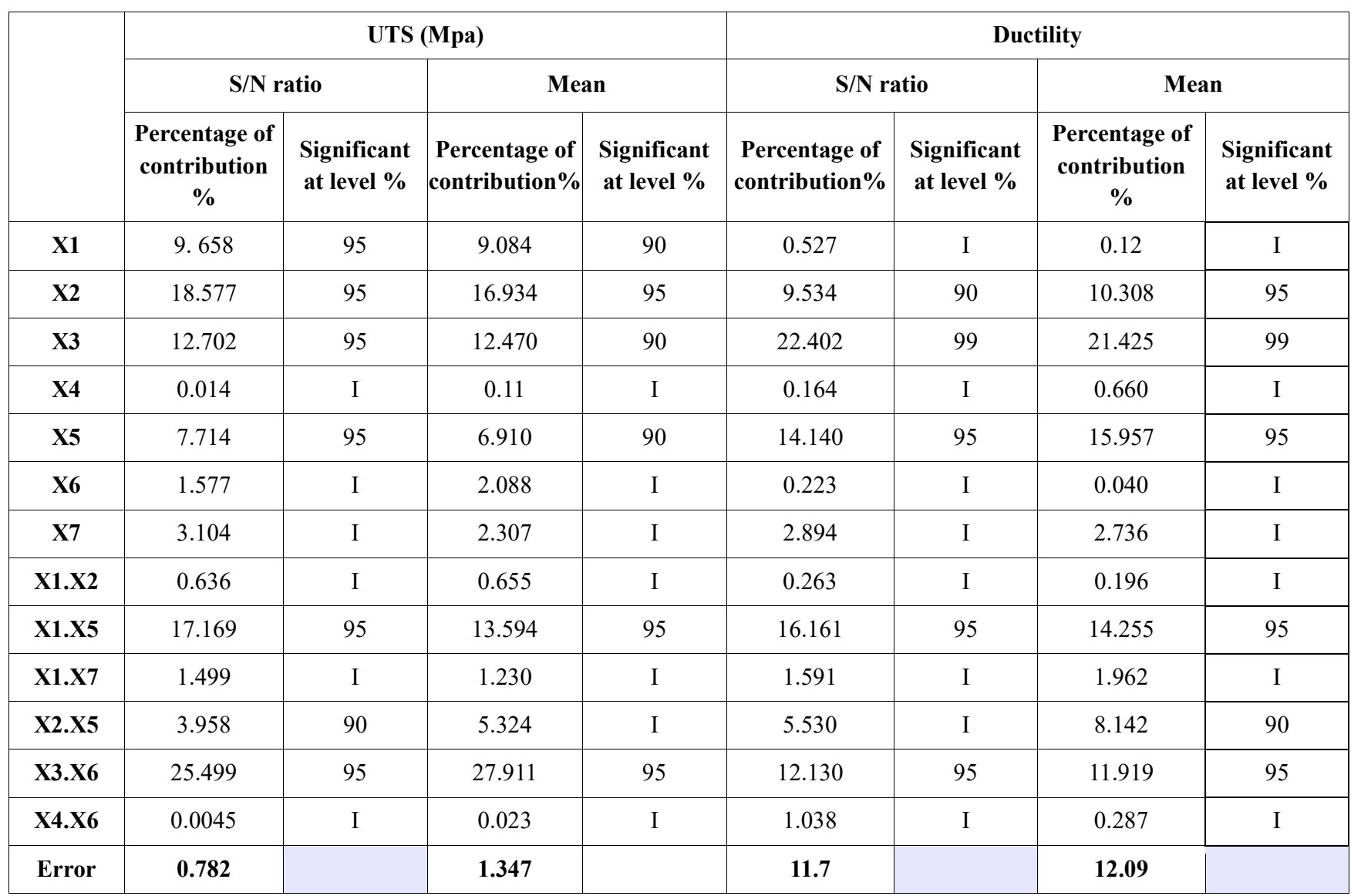

I: Insignificant at any confidence levels $(90 \%, 95 \%, 99 \%)$

X1- rotational speed (rpm), X2- traverse speed ( $\mathrm{mm} / \mathrm{min}), \mathrm{X} 3-\mathrm{D} / \mathrm{d}$ ratio, X4- pin profile (based on taper angle), X5- Plunge depth(mm), X6Tilt angle, and $\mathrm{X} 7$ - location of base metal (based on tool rotation direction).

\subsubsection{ANOVA for L16-OA Results of Mean and S/N ratio Shows Some Results:}

\section{A- For Ultimate Tensile Strength}

\section{A.1- Based on S/N Ratio}

- Rotational speed, traverse speed, D/d ratio and plunge depth are significant parameters at 95\% confidence level (C.L.). Pin profile, location of base metal and tilt angle are insignificant parameters at any confidence levels.

- X1.X5 and X3.X6 are significant interactions at 95\% confidence level. Only X2.X5 is significant interaction at 90\% confidence level. Interactions: X1.X2, X1.X7, and X4.X6 are statistically insignificant at any confidence levels.

- The traverse speed and D/d ratio and the interactions of X1.X5 and X3.X6 have the most contribution to the process and totally contribute about $73.947 \%$ for $\mathrm{S} / \mathrm{N}$ ratio to overall contributions. The traverse speed has the highest contribution to the process about $18.577 \%$ as in references [4] 35\% and [20] 33\% but the traverse speed in some previous processes of joining aluminum alloys has the second highest contribution to the process as in references [8] 13.40\%, [10] $29.8 \%$, [11] 32.24\% and [21] 28.3\%, The D/d ratio has the second highest contribution to the process about $12.702 \%$. Some of the previous processes of joining aluminum alloys show that the rotational speed has the highest contribution to the process instead of traverse speed and D/d ratio as $68.13 \%$ [8], 53.55\% [10], 41.25\% [11] and $67 \%$ [21]. The change in contribution percentage 
Elnabi et al., Adv.J. Grad. Res.; Vol. 4, Issue 1, pp: 1-14, July 2018

of parameters to the process depends on the levels of its parameters, the other parameters applied in this process and the process condition [27].

- It can ignore the effect of the insignificant parameters and the insignificant interactions when performing the process or develop a mathematical model for the response, especially if the parameters have a very low contribution to the response. It can neglect the effects of pin profile, location of base metal, tilt angle and the interactions of X1.X2, X1.X7 and X4.X6 which totally have a contribution of $6.8 \%$ to the system output.

- The optimum levels of the process parameters which can be used to obtain the optimum value are rotational speed at level $2(1225 \mathrm{rpm})$, traverse speed at level $2(21 \mathrm{~mm} / \mathrm{min}), \mathrm{D} / \mathrm{d}$ ratio at level 1 (3), pin profile at level 1 (based on the taper angle $0^{\circ}$ (cylinder)), plunge depth at level $1(0.1 \mathrm{~mm})$, tilt angle at level $2\left(2^{\circ}\right)$ and location of base metal (lower metal, based on the tool rotation direction) at level 2 (advancing side 360\%).

\section{A.2- Based on Mean (ANOM)}

- Only traverse speed is significant parameters at 95\% confidence level. Rotational speed, D/d ratio and plunge depth are significant parameters at 90\% C.L. Pin profile, tilt angle and location of base metal are insignificant parameters at any C.Ls.

- Interactions: X1.X5 and X3.X6 are statistically significant at 95\% C.L. Interactions: X1.X2, X1.X7, $\mathrm{X} 2 . \mathrm{X} 5$ and X4.X6 are statistically insignificant at any C.Ls.

- The traverse speed and D/d ratio and the interactions of X1.X5 and X3.X6 have the most contribution to the process and totally contribute about $71 \%$ for mean to overall contributions. The traverse speed has the highest contribution to the process about $16.943 \%$ as in reference [20] $34 \%$ but the traverse speed in some previous processes of joining aluminum alloy has the second highest contribution to the process as in references [8] $13.70 \%$, [10] $30.17 \%$, [11] 33.24\% and [21] $28.3 \%$. The $\mathrm{D} / \mathrm{d}$ ratio has the second highest contribution to the process about $12.470 \%$. Some of the previous processes of joining aluminum alloys show that the rotational speed has the highest contribution to the process instead of traverse speed and $\mathrm{D} / \mathrm{d}$ ratio as $68.13 \%$ [8], $52.60 \%$ [10] $41.30 \%$ [11] and $67 \%$ [21],

- It can neglect the effect of the insignificant parameters (pin profile, tilt angle and location of base metal) and the insignificant interactions (X1.X2, X1.X7, X2.X5 and X4.X6) which totally have a contribution of $11.7 \%$ on the response when develops the model.

- The optimum levels which can be used to obtain the highest UTS within the process condition are rotational speed at level $2(1225 \mathrm{rpm})$, traverse speed at level $2(21 \mathrm{~mm} / \mathrm{min}), \mathrm{D} / \mathrm{d}$ ratio at level 1 (3), pin profile at level 2 (based on the taper angle $\left(17^{\circ}\right)$ ), plunge depth at level $1(0.1 \mathrm{~mm})$, tilt angle at level $2\left(2^{\circ}\right)$, location of base metal (lower metal, based on the tool rotation direction) at level 2 (advancing side $360^{\circ}$ ).

\section{B- For Ductility}

\section{B.1- Based on S/N Ratio}

- D/d ratio, plunge depth and traverse speed are significant parameters at 99 \%, 95\%, 90\% confidence level, respectively. Rotational speed, pin profile, tilt angle and the location of base metal are insignificant parameters at any confidence levels.

- Interactions: X1.X5 and X3.X6 are statistically significant at 95\% C.L. Interactions: X1.X2, X1.X7, $\mathrm{X} 2 . \mathrm{X} 5$ and $\mathrm{X} 4 . \mathrm{X} 6$ are statistically insignificant at any C.Ls.

- The traverse speed, $\mathrm{D} / \mathrm{d}$ ratio, plunge depth and the statistical interactions between rotational speed and plunge depth and between $\mathrm{D} / \mathrm{d}$ ratio and tilt angle have the most contribution to the process and totally contribute about $74.63 \%$ for $\mathrm{S} / \mathrm{N}$ ratio to overall contributions. The $\mathrm{D} / \mathrm{d}$ ratio 
has the highest contribution to the process about $22.402 \%$.

- It can neglect the effect of the insignificant and the insignificant interactions which totally have a contribution of $13.67 \%$ on the response when develops the model.

- The optimum levels of the process parameter which can be used to achieve the optimum value are rotational level at level $2(1225 \mathrm{rpm})$, traverse speed at level $2(21 \mathrm{~mm} / \mathrm{min}), \mathrm{D} / \mathrm{d}$ ratio at level 1 (3), pin profile at level 1 (based on the taper angle $\left.0^{\circ}\right)$, plunge depth at level $1(0.1 \mathrm{~mm})$, tilt angle at level $1\left(1.5^{\circ}\right)$, and the location of base metal (lower metal, based on the tool rotation direction) at level 2 (advancing side $360^{\circ}$ ).

\section{B.2- Based on Mean (ANOM)}

- $\mathrm{D} / \mathrm{d}$ ratio, plunge depth and traverse speed are significant parameters at $99 \%, 95 \%, 95 \%$ confidence level, respectively. Rotational speed, pin profile, tilt angle and the location of base metal are insignificant parameters at any confidence levels.

- Interactions: X1.X5, X2.X5 and X3.X6 are statistically significant at $95 \%$, 90\%, 95\% C.L. Interactions: X1.X2, X1.X7 and X4.X6 are statistically insignificant at any C.Ls.

- The traverse speed, D/d ratio, plunge depth and the statistical interactions between welding speeds and plunge depth and between $\mathrm{D} / \mathrm{d}$ ratio and tilt angle have the most contribution to the process and totally contribute about $82.006 \%$ for $\mathrm{S} / \mathrm{N}$ ratio to overall contributions. The $\mathrm{D} / \mathrm{d}$ ratio has the highest contribution to the process about $21.425 \%$.

- It can neglect the effect of the insignificant and the insignificant interactions which totally have a contribution of $5.90 \%$ on the response when develops the model.

- The optimum levels which can be used to obtain the maximum ductility within the process condition are rotational level at level $2(1225 \mathrm{rpm})$, traverse speed at level $2(21 \mathrm{~mm} / \mathrm{min}), \mathrm{D} / \mathrm{d}$ ratio at level 1 (3), pin profile at level 1 (based on the taper angle $0^{\circ}$ ), plunge depth at level $1(0.1$ $\mathrm{mm})$, tilt angle at level $1\left(1.5^{\circ}\right)$, and the location of base metal (lower metal, based on the tool rotation direction) at level 2 (advancing side $\left.360^{\circ}\right)$.

\subsection{Response Surface Methodology (RSM)}

Response Surface Methodology attempts to analyze the influence of the independent variables on a specific response. The purpose of mathematical models relates the process responses to process variables. The mathematical model commonly used for the process responses is represented as:

$$
\mathrm{Y}=\mathrm{F}\left(\mathrm{X}_{1}, \mathrm{X}_{2}, \ldots . ., \mathrm{Xn}\right)+f
$$

Where: Y: response (output); $\mathrm{X}$ : process variables; $f$ : noise or error value The coefficient of process parameters using RSM is represented as

$$
\mathrm{B}]=\text { Inverse }\left([\mathrm{Z}]^{\mathrm{T} *}[\mathrm{Z}]\right)^{*}[\mathrm{Z}]^{\mathrm{T} *}[\mathrm{~F}]
$$

Where: [B]: array of coefficients of process parameters, [Z]: orthogonal array with values of selected process parameters, $[\mathrm{F}]$ : array with values of measured response, and $[\mathrm{Z}]^{\mathrm{T}}$ :transpose array of $[\mathrm{Z}]$.

Residuals are the different between the responses determined from the experiments and the responses predicted from the model, and the percentage of the deviation of a single sample data can be calculated from Eq.4.

$$
\text { Deviation }=\left[\left(\text { Absolute }\left[\mathrm{R}_{\text {measured }}-\mathrm{R}_{\text {predicted }}\right]\right) /\left(\mathrm{R}_{\text {measured }}\right)\right]^{*} 100
$$

Where, R: response

The models for UTS and ductility based on S/N ratio and mean are developed by adding only the significant parameters and the significant interactions as in equations 5, 6, 7 and 8 . The variations between the measured results and the model results are given in figures 5, 6, 7 and 8 . The accuracy of the models represents the accuracy of the prediction of the output. The accuracy of the models developed for the 
Elnabi et al., Adv.J. Grad. Res.; Vol. 4, Issue 1, pp: 1-14, July 2018

UTS and ductility based on the mean and S/N ratio is very high: (UTS: $99.56 \%$ for $\mathrm{S} / \mathrm{N}$ ratio and $97.6 \%$ for mean; ductility: $97.3 \%$ for $\mathrm{S} / \mathrm{N}$ ratio and $93.5 \%$ for mean). It is mean that the significant process parameters and significant interactions used to develop the models approximately have the most contribution to the output of the process and any other parameters and statistical interactions which don't add in the models have a very small impact on the output.

$\mathrm{UTS}_{\mathrm{s} / \mathrm{n} \text { ratio }}=-46.2120-0.0021 * \mathrm{X}_{1}+0.1822 * \mathrm{X}_{2}-0.449 * \mathrm{X}_{3}-11.4541 * \mathrm{X}_{5}$

$+0.0182 * \mathrm{X}_{1} \cdot \mathrm{X} .0 .5400 * \mathrm{X}_{2} \cdot \mathrm{X}_{5}+0.0902 * \mathrm{X}_{3} \cdot \mathrm{X}_{6}$

$\mathrm{UTS}_{\text {mean }}=246.11-0.045 * \mathrm{X}_{1}+1.899 * \mathrm{X}_{2}-10.50 * \mathrm{X}_{3}-481.24 * \mathrm{X}_{5}+0.40 * \mathrm{X}_{1} \cdot \mathrm{X}_{5}-2.27 * \mathrm{X}_{3} \cdot \mathrm{X}_{6}$

Ductility $\operatorname{mean}=3.831+0.446 * \mathrm{X}_{2}-0.889 * \mathrm{X}_{3}+20.417 * \mathrm{X}_{5}+0.006 * \mathrm{X}_{1} \cdot \mathrm{X}_{5}-1.720 * \mathrm{X}_{2} \cdot \mathrm{X}_{5}$

$+0.0297 * \mathrm{X}_{3} \cdot \mathrm{X}_{6}$

Ductilitys/N ratio $=19.655+0.145 * \mathrm{X}_{2}-0.898 * \mathrm{X}_{3}-15.70 * \mathrm{X}_{5}+0.0098 * \mathrm{X}_{1} \cdot \mathrm{X}_{5}+0.0025 * \mathrm{X}_{3} \cdot \mathrm{X}_{6}$

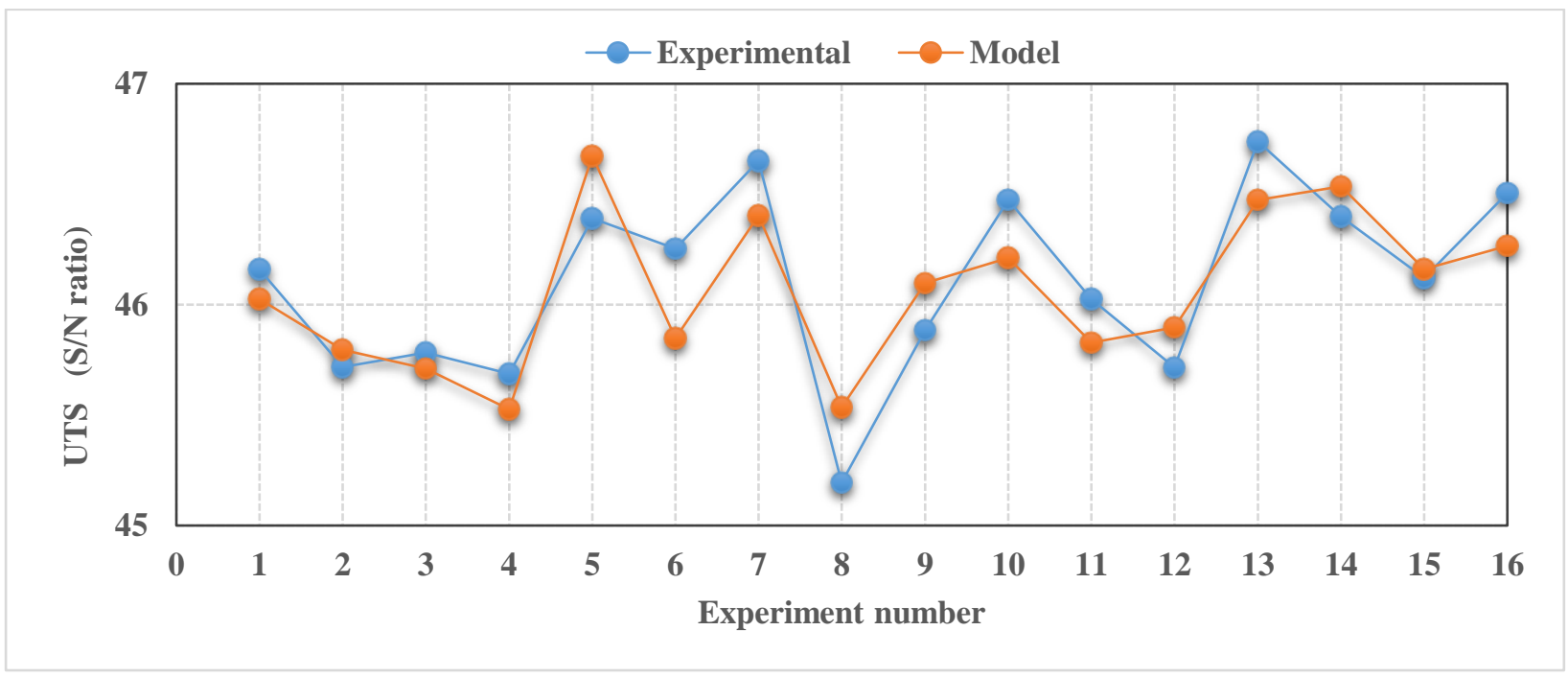

Figure 5: Measured UTS Vs. Model UTS (S/N ratio)

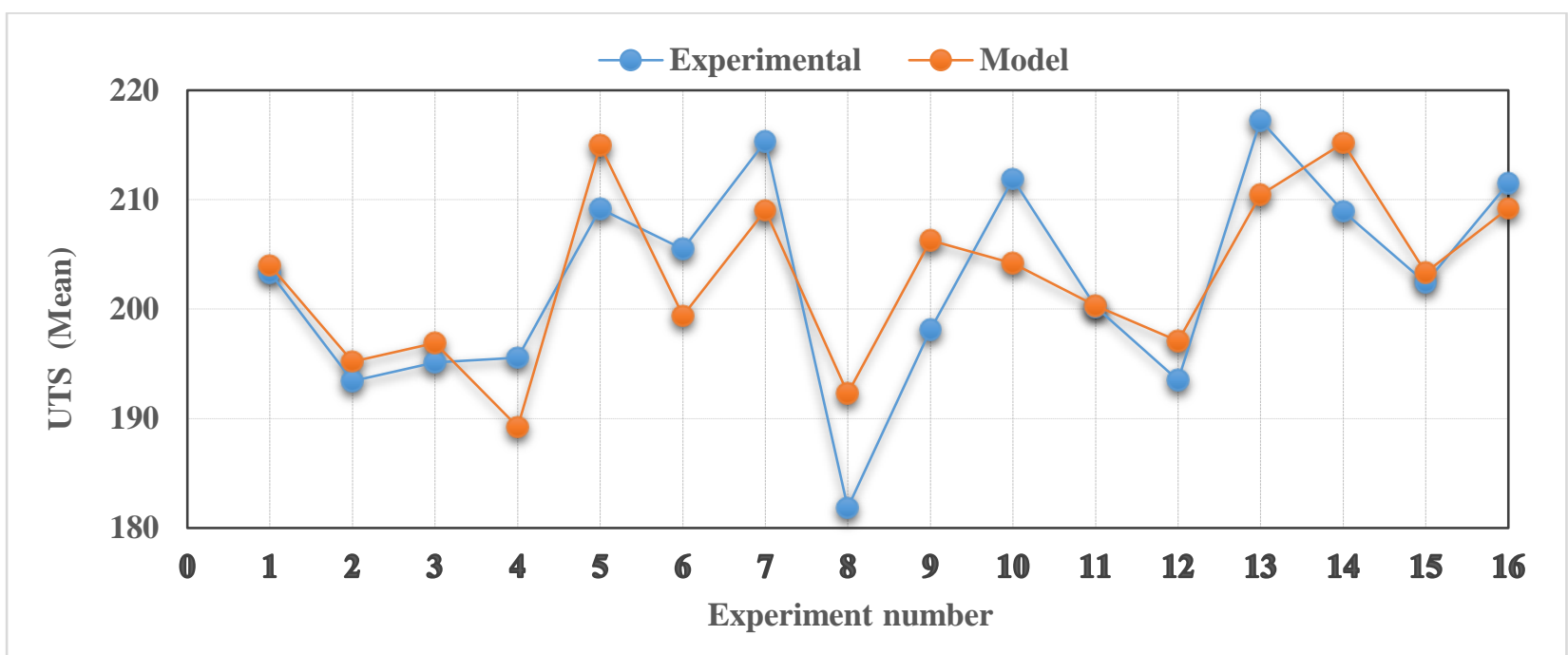

Figure 6: Measured UTS Vs. Model UTS (Mean) 


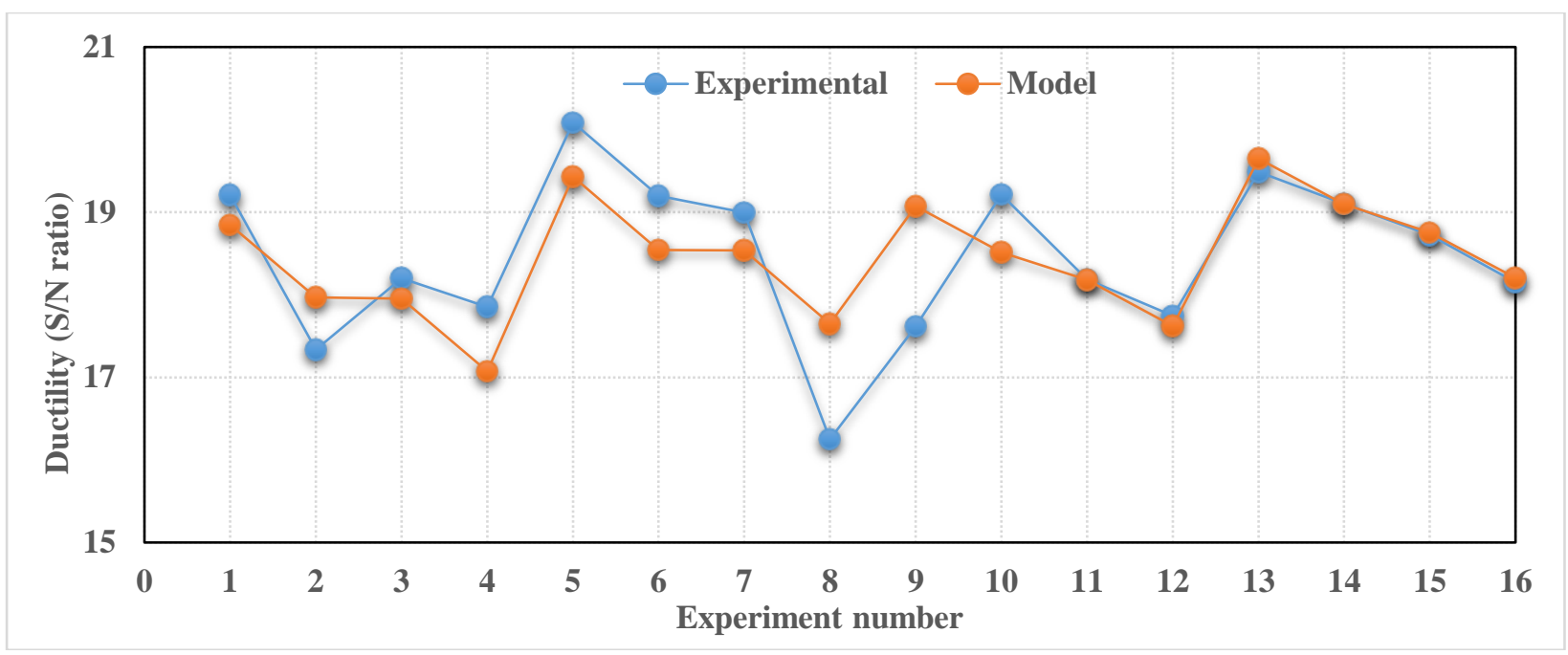

Figure 7: Measured S/N ratio Vs. Model-S/N ratio of ductility

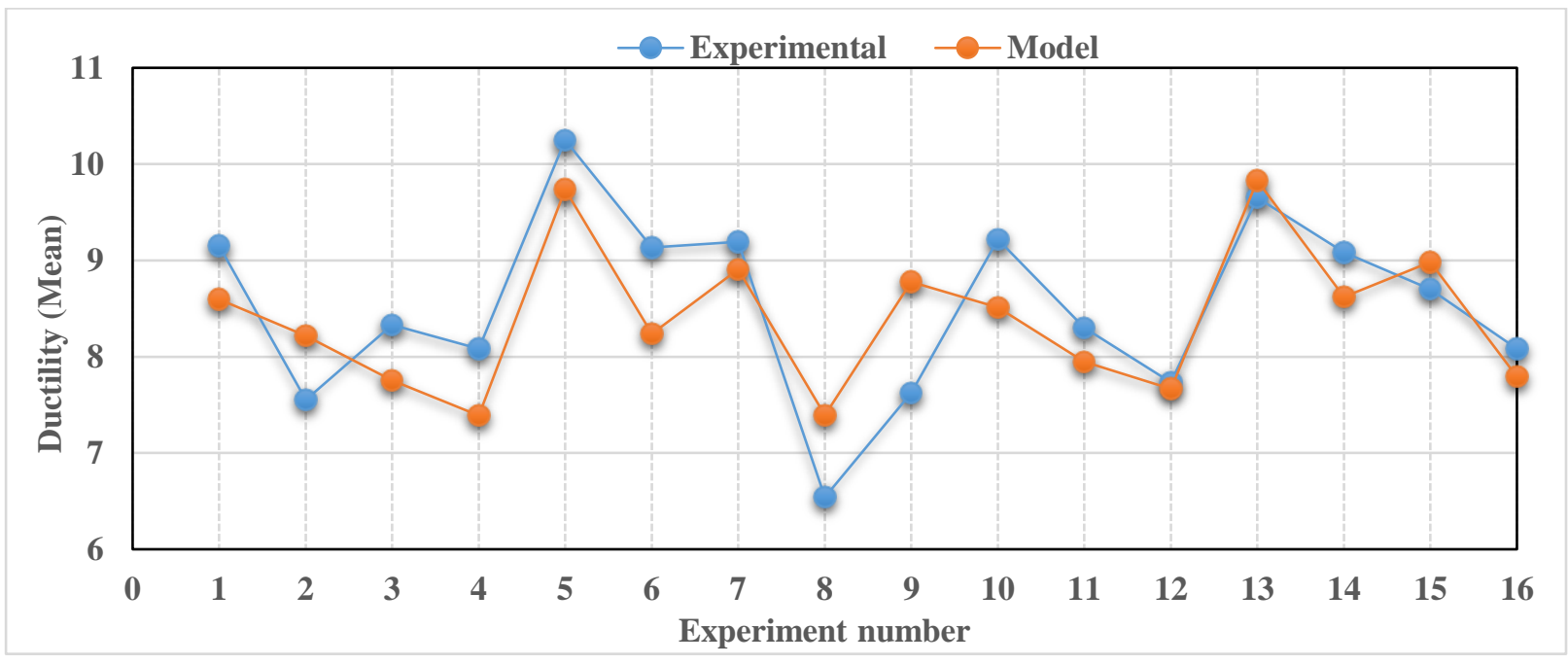

Figure 8: Measured mean ductility Vs. Model mean ductility

The estimated surface plots for UTS and ductility (mean) are given in Figures 9 and 10, respectively. Each plot depicts the effect of two of the five significant parameters found in the models and the other three significant parameters are fixed at low levels. The mean of UTS results is a function of the parameters of $\mathrm{X} 1, \mathrm{X} 2, \mathrm{X} 3, \mathrm{X} 5$ and the interactions of X1.X5 and X3.X6. The mean of ductility results is a function of the parameters of X2, X3, X5 and the interactions of X1.X5, X2.X5, and X3.X6. 

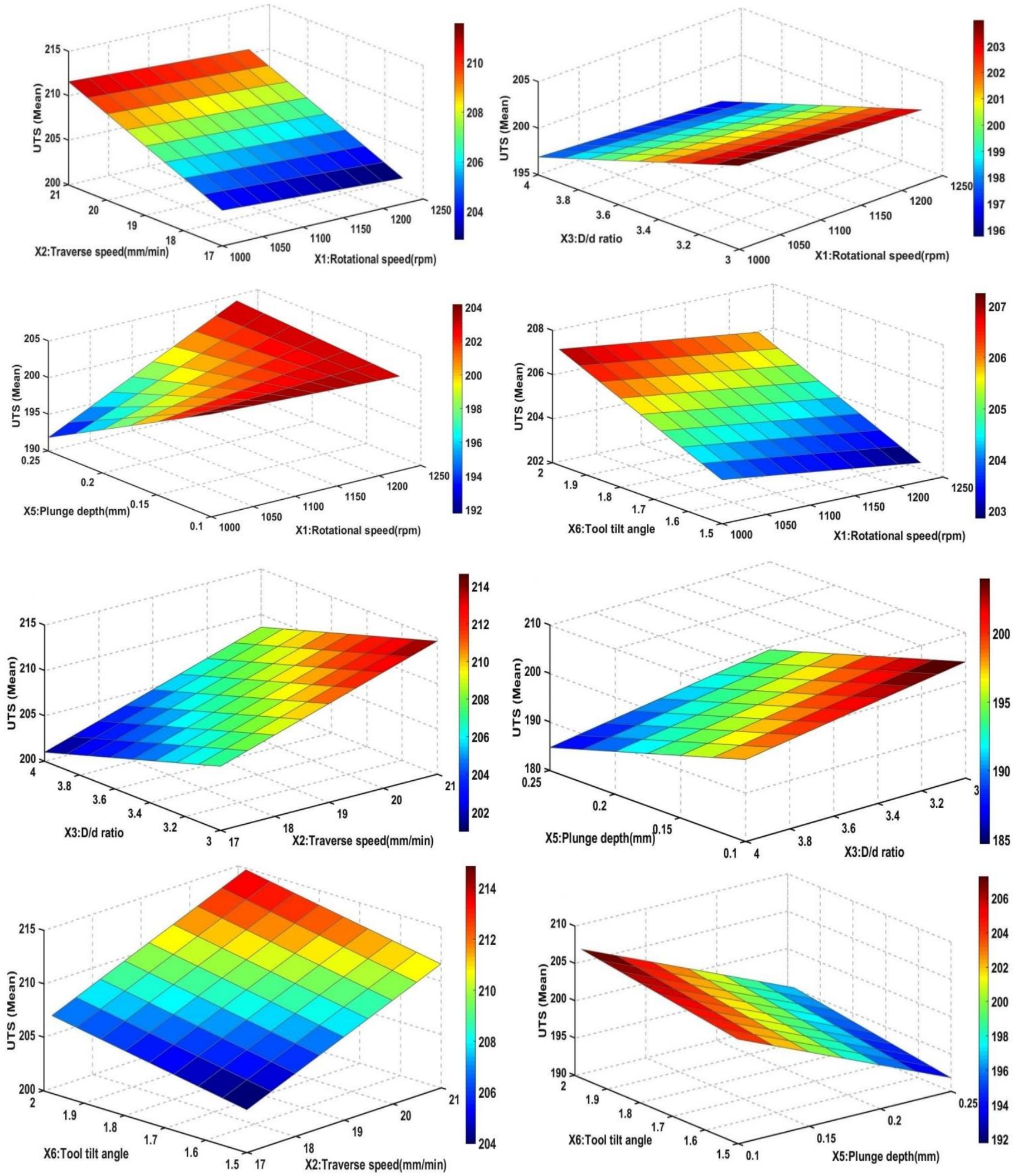

Figure 9: Effect of FSW parameters on UTS (Mean) 

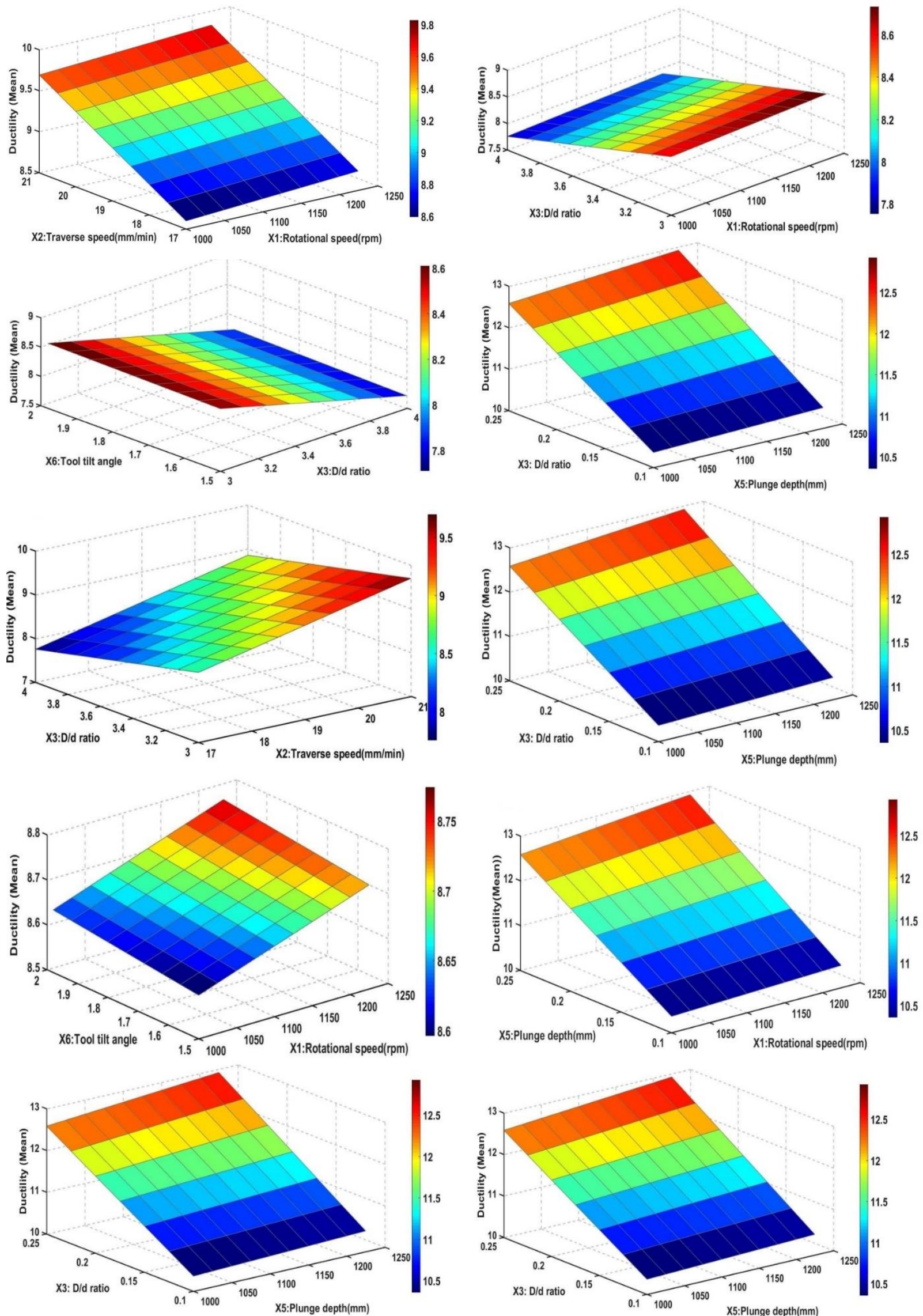

Figure 10: Effect of FSW parameters on ductility (Mean) 


\section{Conclusions}

Modeling and optimization of FSW parameters of AA5454 to AA7075 joints are studied by using Taguchi methods. Taguchi L16-OA was used to optimize the process parameters. Seven parameters at two levels are selected. These parameters are rotational speed, traverse speed, $\mathrm{D} / \mathrm{d}$ ratio, pin profile (based on the taper angle), tool tilt angle, plunge depth, and the location of base metal (based on the tool rotation direction). UTS and ductility were considered as the mechanical properties of the dissimilar joint. The results can be summarized as follows:

For UTS: based on S/N ratio and mean, Rotational speed; traverse speed; D/d ratio and plunge depth are significant parameters at different confidence levels. Pin profile; location of base metal and tilt angle are insignificant parameters at any confidence levels. Based on the results of $\mathrm{S} / \mathrm{N}$ ratio and mean of ductility: $\mathrm{D} / \mathrm{d}$ ratio, plunge depth and traverse speed are significant parameters at $99 \%, 95 \%$, and $90 \%$ confidence level, respectively. Rotational speed, pin profile, tilt angle and the location of base metal are insignificant parameters at any confidence levels. Four mathematical models were developed for UTS and ductility as a function of the significant parameters and the significant interactions. For UTS, the accuracy of the models is $97.678 \%$ and $99.56 \%$ for mean and $\mathrm{S} / \mathrm{N}$ ratio, respectively. For ductility, the accuracy of the models is $93.56 \%$ and $97.320 \%$ for mean and $\mathrm{S} / \mathrm{N}$ ratio, respectively. The optimal levels determined from the L16OA to obtain the highest UTS within process condition are $0.1 \mathrm{~mm}$ plunge depth, $1225 \mathrm{rpm}$ rotational speed, tapered pin profile, $21 \mathrm{~mm} / \mathrm{min}$ traverse speed, 20 tilt angle, $3 \mathrm{D} / \mathrm{d}$ ratio, and AA5454 on the advancing side. The maximum joint efficiency obtained, compared to the strength of the softer metal used in the dissimilar joint, is $85.3 \%$. The optimal levels determined from the L16-OA to achieve the highest ductility within process condition are $0.1 \mathrm{~mm}$ plunge depth, $1225 \mathrm{rpm}$ rotational speed, cylindrical pin profile, $21 \mathrm{~mm} / \mathrm{min}$ traverse speed, $1.5^{\circ}$ tilt angle, $3 \mathrm{D} / \mathrm{d}$ ratio, and AA5454 on the advancing side.

\section{How to Cite this Article:}

M. M. Abd Elnabi, T. Osman, A. El Mokadem, and A. Elshalakany, "Modeling and Optimization of Friction Stir Welding Parameters for Joining Dissimilar Aluminum Alloys", Advanced Journal of Graduate Research, vol. 4, no. 1, pp. 1-14, Apr. 2018. doi: 10.21467/ajgr.4.1.1-14

\section{References}

[1] R. S. Mishra and Z. Y. Ma, "Friction Stir Welding and Processing," Materials Science and Engineering: R: Reports, Vol. 50, Issues12, pp. 1-78, 2005

[2] A. Steuwer, M. J. Peel and P.J. Withers, "Dissimilar Friction Stir Welds in AA5083-AA6082. Part I: Process Parameter Effects on Thermal History and Weld Properties," Mater Sci Eng A, Vol. 37A, pp.2183-2193. 2006.

[3] K. Dehghani, R. Ghorbani and A. R. Soltanipoor, "Microstructural evolution and mechanical properties during the friction stir welding of 7075-O aluminum alloy," Int J Adv Manuf Technol, Vol. 77, Is. 9-12, pp. 1671-1679, 2015.

[4] Ram and Jane Kumar, "Parametric Optimization for Friction Stir Welding of AL 6063 Alloy Using Taguchi Technique," IJSTE, Vol. 6, Issue 4, pp.604-610, 2016

[5] V. Ramgopal, B. Abdullah, A. Mohammed and Y. Yaswanth, "STRUCTURAL PROPERTIES OF SIMILAR AND DISSIMILAR ALUMINUM ALLOY JOINTS BY FSW," ASME International Mechanical Engineering Congress and Exposition, Vol. 2B: Advanced Manufacturing:V02BT02A002, 2014.

[6] P. Sadeesh, M. V. Kannan, V. Rajkumar, P. Avinash, N. Arivazhagan, K. D. Ramkumar, and Narayanan, " Studies on friction stir welding of AA 2024 and AA 6061 dissimilar metals, " Procedia Engineering 75, pp. 145 -149, 2014.

[7] A. S. Vagh1 and S. N. Pandya, "influence of process parameters on the mechanical properties of friction stir welded aa 2014-t6 alloy using Taguchi orthogonal array," IJESET, Vol. 2, Issue 1, pp: 51-58, 2012.

[8] P. M. Krishna, N. Ramanaiah and K. P. Rao,"Optimization of process parameters for Friction Stir welding of dissimilar Aluminum alloys (AA2024 -T6 and AA6351-T6) by using Taguchi method," International Journal of Industrial Engineering Computations 4, pp.71-80, 2013.

[9] N. T. Kumbhar and K. Bhanumurthy, "Friction StirWelding of Al 5052 with Al 6061 Alloys", Hindawi-Journal of Metallurgy, Vol. 2012, 2012

[10] M. Jayaraman, R. Sivasubramanian, V. Balasubramanian and A. K. Lakshminarayanan,"Optimization of process parameters for friction stir welding of cast aluminum alloy A319 by Taguchi method," Journal of Scientific \& Industrial Research, Vol. 68, pp. 36-43, 2009.

[11] A. K. LAKSHMINARAYANAN and V. BALASUBRAMANIAN, "Process parameters optimization for friction stir welding of RDE40 aluminium alloy using Taguchi technique," Trans Nonferrous Met. Soc. China, Vol. 18, pp. 548-554, 2008. 
[12] M. J. PEEL, A. STEUWER, P. J. WITHERS, T. DICKERSON, Q. SHI and H. SHERCLIFF, "Dissimilar Friction Stir Welds in AA5083-AA6082. Part I: Process Parameter Effects on Thermal History and Weld Properties, " METALLURGICAL AND MATERIALS TRANSACTIONSA, Vol. 37A, pp. 2183-2193, 2006.

[13] M. M. Abd Elnabi, T. A. Osman, A. El Mokadem and A. B. Elshalakany, "Mechanical properties and macrostructure of dissimilar friction stir welding of aluminum alloys," International Journal of Development Research, Vol. 7, pp. 11884-11888, 2017.

[14] K. Mallieswaran, R. Padmanabhan and V. Balasubramanian, "Friction stir welding parameters optimization for tailored welded blank sheets of AA1100 with AA6061 dissimilar alloy using response surface methodology," Advances in Materials and Processing Technologies, pp. 1-16, 2018.

[15] A. Goyal, P. K. Rohilla and A. K. Kaushik, "Optimization of Friction Stir Welding Parameters for AA3003 Aluminum Alloy Joints Using Response Surface Methodology," International Journal of Mechanics and Solids, Vol. 9, pp.15-22, 2017.

[16] K. K. Babu, K. Panneerselvam, P. Sathiya, A. N. Haq, S. Sundarrajan, P. Mastanaiah and C. V. S. Murthy, "Parameter optimization of friction stir welding of cryorolled AA2219 alloy using artificial neural network modeling with genetic algorithm," Int J Adv Manuf Technol, pp. 1-15. 2017.

[17] P. G. Kohak and R. R. Navthar," Optimization of Process parameters of Friction Stir Welding for Similar HE-30 Aluminium Alloy," IRJET, Vol. 4, pp. 1040-1048, 2017.

[18] S. Jaina, N. Sharma and R. Gupta, "Dissimilar alloys (AA6082/AA5083) joining by FSW and parametric optimization using Taguchi, grey relational and weight method ," Engineering Solid Mechanics, Vol. 6, pp. 51-66, 2018.

[19] R. Sandeep, D. Sudhakara, G. Prasanthi, "Optimization of Friction Stir Welding Process Parameters to Join Al 5052 and Al 6061 Alloy Plates Using Grey-Taguchi Technique," ASME. International Manufacturing Science and Engineering Conference, Vol. 1: Processes ():V001T02A001. 2017.

[20] D. Ram and G. Mahendra, "OPTIMIZATION OF FSW PROCESS PARAMETER TO ACHIEVE MAXIMUM TENSILE STRENGTH OF ALUMINUM ALLOY AA6061," IRJET, Vol. 3, Is. 2, pp.936-943, 2016.

[21] Saurabh Kumar Gupta, K.N. Pandey, "Application of Taguchi Method for Optimization of Friction Stir Welding Process Parameters to Joining of Al Alloy," Advanced Materials Manufacturing \& Characterization, Vol. 3, Issue 1, pp.253-258, 2013.

[22] R. Rafiei, M. Shamanian and M. Fathi, "Dissimilar friction-stir lap-welding of aluminum-magnesium (AA5052) and aluminum-copper (AA2024) alloys: microstructural evolution and mechanical properties," Int J Adv Manuf Technol, pp. 1-18, 2017.

[23] O. M. R. Elfar, R. M. Rashad and H. Megahed, " Process Parameters Optimization for Friction Stir Welding of Pure Aluminium to Brass (CuZn30) using Taguchi Technique", MATEC Web of Conferences, Vol. 43, 2016.

[24] K. P. Mehta and V. J. Badheka," A Review on Dissimilar Friction Stir Welding of Copper to Aluminum: Process, Properties, and Variants," Materials and Manufacturing Processes, Vol. 31, pp. 233-254, 2016.

[25] Z. Boumerzoug and Y.Helal, " Friction Stir Welding of Dissimilar Materials Aluminum AL6061-T6 to Ultra Low Carbon Steel, " Metals, Vol. 7(2), pp. 42, 2017.

[26] M. Pourali, A. bdollah-zadeh, T. Saeid and F. Kargar, "Influence of welding parameters on intermetallic compounds formation in dissimilar steel/aluminum friction stir welds," Journal of Alloys and Compounds, Vol. 715, pp. 1-8, 2017.

[27] Phillip J. ROSS, 1998, "Taguchi technique for quality engineering”, Second edition, Mcgraw-hill, Donnelley\& Sons company, ISBN0-07-053958-8, pp. 1-327.

[28] ASTM B557-15, Standard Test Methods for Tension Testing Wrought and Cast Aluminum- and Magnesium-Alloy Products, ASTM International, West Conshohocken, PA, 2015.

\section{Publish your research article in AIJR journals-}

$\checkmark$ Online Submission and Tracking

$\checkmark$ Peer-Reviewed

$\checkmark$ Rapid decision

$\checkmark$ Immediate Publication after acceptance

$\checkmark$ Articles freely available online

$\checkmark$ Retain full copyright of your article.

Submit your article at journals.aijr.in
Publish your books with AIJR publisher-

$\checkmark$ Publish with ISBN and DOI.

$\checkmark$ Publish Thesis/Dissertation as Monograph.

$\checkmark$ Publish Book Monograph.

$\checkmark$ Publish Edited Volume/ Book.

$\checkmark$ Publish Conference Proceedings

$\checkmark$ Retain full copyright of your books.

Submit your manuscript at books. aijr.org 